\title{
Cultural Issues in Indonesian Language Learning for Foreign Speakers
}

\author{
Ichsan Fauzi Rachman ${ }^{1}$, Andayani ${ }^{2}$, Suyitno ${ }^{3}$
}

\section{ARTICLE INFO}

Article History:

Received 04.01.2019

Received in revised form

09.04.2019

Accepted

Available online 01.07.2019

\begin{abstract}
This study shows that the existence of culture in Indonesian language learning for foreign speakers (BIPA) has an important role. In addition to being used to enrich teaching materials in BIPA learning, cultural content is able to introduce Indonesian cultural identity to the international realm, both locally and nationally. Cultural content in BIPA learning is also one of the strategic steps that can be applied as a strategy to face MEA. Through cultural-based BIPA learning, it is expected that foreign students who learn Indonesian will be closer and know about multiculturalism in Indonesia. This research was conducted at State Universities in Surakarta City, namely UNS and IAIN. Data collection techniques are carried out in three ways, namely (1) Observation, (2) document analysis, and (3) interview. The data validity technique in this study is triangulation technique. Meanwhile, the studies discussed in the study were about the implementation of culture-based Indonesian language learning carried out at state universities holding the BIPA program in Surakarta and several relevant literature studies.
\end{abstract}

C IJERE. All rights reserved

Keywords:

Culture, Bipa, Learning, Indonesian language

\section{INTRODUCTION}

learning is an important aspect that must be taught in order to strengthen the sense of love of the younger generation of unique and diverse Indonesian languages and cultures. However, currently learning Indonesian is not only taught to native speakers but the learning program has begun to expand to the international world. Mastery of a good language will certainly help the community to be able to communicate globally in many fields. This is the thing that underlies the existence of Indonesian language learning starting to expand at the international level. According to data from the Language Center in Jakarta, the Indonesian Language teaching program for Foreign Speakers (BIPA) has been held in around 46 countries in the world (Azizah et al. 2012: 1).

Culture-based BIPA learning is one step that can be applied to foreign students who want to learn Indonesian. Based on many studies, today, language educators have emphasized the importance of the value of maintaining heritage languages, not only as personal resources, but also as social resources (Brecht \& Ingold, 1998; Brecht \& Walton, 1993). Therefore, it is very important if Indonesian language learning for foreign speakers must be integrated with an introduction to the underlying cultural concepts. With language learning using cultural issues, it is expected that foreign learners will find it helpful to achieve the required competency and mastery standards of Indonesian language and will also equip BIPA learners about Indonesian language skills and knowledge of Indonesian culture. The introduction of culture found in Indonesia needs to be done, namely to broaden students' knowledge about Indonesian culture. Julianto et al. (2018) suggested that through education it could be useful to pass on the local culture to the younger generation so as not to be degraded by modernization. This is because in the era of globalization many people slowly began to apathy with the values of local wisdom as part of a multicultural nation in culture.

However, in addressing the new culture, Lambert (1975) suggested that there were four possible adjustments made by minority language students who were studying foreign languages in one place, namely (1) The students could reject the language and culture of their inheritance. ; (2) he can reject the broader / dominant language and culture of society, (3) he can become an anomic individual without affiliation with their own culture or wider / dominant culture; and finally (4) he became comfortable bilingual and bicultural and was able to participate fully in both cultures. However, the ideal alternative is to integrate the two cultures to form a unique bicultural identity (Hamers \& Blanc, 1993). From a bilingual-bicultural base, BIPA students can increase their tolerance and respect for human diversity, including in Indonesia (Lambert, 1975: 79). According to LaFromboise et al. (1993), biculturalism assumes that it is possible for someone to know and understand two different cultures. This also presupposes that an individual can change his behavior to fit a particular social context. In addition, this concludes that a person can have a sense of belonging in two cultures without reducing his cultural sense of identity. 
Rachman,I.F., Andayani \& Suyitno (2019). Cultural issues in Indonesian language learning for foreign speakers. International Journal of Educational Research Review,4(3),454-460.

In BIPA learning, learning content that contains local cultural values is an important thing to do to provide an understanding of diverse Indonesian culture so that it will help foreign learners to interact and adapt in the Indonesian state. BIPA learning is not only intended so that learners master verbal language only but the concept of culture and customs of Indonesian society which is also an important component to be known by foreign learners in learning Indonesian.

With the existence of culture-based BIPA learning, it is expected to help the process of internationalizing Indonesian language and culture. BIPA students can get to know Indonesian language and culture so well that it will become a provision for them to settle in Indonesia. The designed learning will certainly also have an effect in introducing and providing an understanding of language as well as Indonesian culture that is unique in the eyes of the international community. Thus, BIPA students at least not only master the Indonesian language rules but can communicate well and correctly in accordance with the context of Indonesia's multicultural culture.

\section{Situation of the Problem}

In this study, researchers tried to explain the importance of cultural issues in BIPA learning in the standard of foreign language mastery, cultural aspects being one of the five standards, where cultural aspects cannot be separated from the other four standards. The five standards that must be obtained by foreign students include: (1) communication, (2) culture, (3) connection, (4) comparison, and (5) community. Therefore, foreign students will be involved in multilingual and multicultural communities.

\section{Aim of the Study}

The aims of this study is to describe the importance of cultural issues in BIPA learning. Where cultural aspects become one of the foreign language mastery standards that must be truly considered, so that foreign learners can understand Indonesian in accordance with the context of the Indonesian culture.

\section{METHOD}

This research was conducted at the State University in Surakarta City. The problems discussed in this study are emphasized in the implementation of culture-based Indonesian language learning carried out in state universities holding the BIPA program in Surakarta and several relevant literature studies. Sources of data in this study include: (1) Documents used in this study are learning material used in cultural-based Indonesian language learning in Surakarta city state universities, the results of transcripts of interviews, and observations; (2) Informant; selected informants were Indonesian language lecturers for foreign speakers and students from Indonesian language learning programs for foreign speakers (BIPA). Sampling uses purposive sampling. Purposive sampling aims to get complete data in various circumstances. The samples used in this study were student representatives from Sebelas Maret University (UNS) and the State Islamic Institute (IAIN) each of 5 students. In addition, researchers also used teaching samples of 2 people from each state university. The object of the study included learning Indonesian for foreign speakers at the Surakarta city state universities, namely UNS and IAIN. Data collection techniques are carried out in three ways, namely (1) Observation, (2) document analysis, and (3) interview. The data validity technique in this study is triangulation technique. Triangulation is a data validity technique that uses something from data to check or compare with other data. The triangulation technique used by researchers is data source triangulation and method triangulation.

\section{Material}

Data in this study include the results of classroom observations conducted by researchers for seven months at the State University in Surakarta, namely Sebelas Maret University and Islamic Institute in Surakarta City. In addition to observational data, researchers also use the results of interviews, both for BIPA students, as well as for teachers. 
Rachman,I.F., Andayani \& Suyitno (2019). Cultural issues in Indonesian language learning for foreign speakers. International Journal of Educational Research Review,4(3),454-460.

\section{Data Analyses}

Analysis techniques in this study used interactive analysis techniques. Interactive model analysis is the interaction of components, namely data collection, data presentation, data reduction, and conclusion drawing.

\section{Findings}

Use of cultural issues in Surakarta City State University has been very good when viewed in terms of cultural content to be taught. However, for teaching Indonesian learning by using cultural issues when viewed in terms of presentation, the researchers concluded that they received less attention. This is based on the absence of special media intended for students to understand cultural issues more interestingly and realistically. Though from the results of interviews, it was found that students had a high interest in cultural issues in Indonesia, including cultural issues in Surakarta.

\section{RESULT, DISCUSSION, AND SUGGESTIONS}

\section{The Relationship of Learning and Culture}

The Research of the relationship between culture and learning has been carried out by researchers around the world. Generally, the study states that human learning and development (learning) is strongly influenced by the culture (Lee, 2009; Lee, Spencer, \& Harpalani, 2003; Orellana \& Bowman, 2003). It means that culture has been influenced and influenced by human learning and development. Therefore, researchers continue to investigate cultural considerations in design, teaching, learning, and assessment of learning content. (Hood, Hopson, \& Frierson, 2005; Swartz, 2009; Warikoo, 2009). This investigation is conducted to explain the cultural influences that have made progress in STREAM-based learning school related to literature and higher education literature on e-learning. Therefore, the choice of learning strategies for students require consideration of the role of culture in learning.

\section{Language and Culture Relationships}

Wardhaugh (2002: 2) defines language as a set of rules on how to say or do something with sounds, words, and sentences, not just knowledge of certain sounds, words and sentences. Wardhaugh does not merely state the culture, but also the speech acts that we do are inseparable of their relationship with the environment, and this is the reason, Wardhaugh defines language by consideration of the context. Whereas, Thanasoulas (2001) defines language as a socially inherited device from practices and beliefs that determine the form of human life.

If we want to discuss the relationship between language and culture, we must have an understanding of what refers to culture. Goodenough (1957: 167, taken from Wardhaugh, 2002: 219) describes culture in relation to the responsibilities of its members. He stated that a culture of society consists of whatever the community has to do all its activities by being accepted by its members, including in interacting and playing the role in the community.

Brown (in Supardo, 1988: 29) states that language has a close relationship with culture. Culture is an integral part of the interaction between language and mind. Cultural patterns, customs, and human way of life are expressed in language. A specific point of view of the world is expressed in language. This is in line with what was said by Aslinda and Syafyahya (2010: 11) that language is strongly influenced by culture, everything that exists in culture will be reflected in language. Meanwhile, Chaer and Agustina (2004: 165) state that the relationship between language and culture is a subordinate relationship, where language is under the scope of culture. However, this is not the only main concept, because there are other opinions which state that language and culture have a coordinative relationship, namely an equal or equal height.

Based on these opinions, we can understand that language has a role in culture because basically a culture will be expressed through language, regardless both of the relationship patterns. When we talk about a society condition, basically most of what we are talking about is about culture. For example, when we observe the traditions or customs of a community in a certain area, if the activity involves the language, of course the actor will convey or communicate ideas that are universal which shows the identity of the local community. Likewise, when we carry out the process of learning Indonesian for foreign workers, we 
actually teach Indonesian culture to foreigners implicitly because language is a part of culture. This is in line with Pamungkas (2012: 16) stating that Indonesian language functions as the language of developers of culture, science, and technology. This implies that in capturing the needs of the development of culture, knowledge and technology that can reach the entire area of Indonesia, certainly a language that is understood by all Indonesian.

\section{The Existence of Teaching Indonesian Language for Foreign Speakers (BIPA)}

The existence of BIPA learning both nationally and internationally is getting stronger. This is proved by the raising of foreign students who visit Indonesia. BIPA course institutions increase in number. Moreover, in several well-known universities in Indonesia, such as Sebelas Maret University and Surakarta State Islamic Institute, there are many foreign students who continue their studies in the Indonesian language department. In fact, some of them continue their study up to post-graduate level. This proves how serious the foreigners want to master Indonesian language with various interests. In addition, the Indonesian government has also carried out real actions by delegating several teachers or BIPA instructors to several countries in the world. The BIPA teachers certainly have a very strategic role in introducing the repertoire of Indonesian languages and cultures to the international domain.

The Officials of the Indonesian Foreign Affairs Ministry (in Hudjolly, 2011: 1) stated that there are 45 countries in the world that teach Indonesian in foreign schools, such as Australia, the United States, Canada and Vietnam. In Australia, Indonesian language became the fourth popular language, that is noted about 500 schools teach Indonesian. In Vietnam, since late 2007, the Ho Chi Minh City Regional Government has officially announced Indonesian to be the second language. Consequently, Vietnam becomes the first ASEAN member who establish Indonesian as the second official language in their country. Indonesian language is equated with English, French, and Japanese as the second priority language in Vietnam.

Furthermore, the Ministry of Education and Culture (Kemdikbud) also released Indonesian Language lecturers for Foreign Speakers (BIPA) 2016 on Tuesday (02/16/2016). In this year is targeted that 80 BIPA teachers will be sent to 16 countries. So far 66 selected BIPA teachers have been officially released by the Ministry of Education and Culture at the Ministry of Education and Culture Office, in Jakarta. The Chief of Language Development and Founding Agency of Ministry of Education and Culture (Kemdikbud), Dadang Suhendar, said that 66 instructors were divided into two waves, each of them were walked on provisioning program in January and February 2016. A number of destination countries for sending BIPA teachers were Vietnam, Laos, Thailand, Singapore, Malaysia, Brunei Darussalam, Cambodia, China, Germany, France, Myanmar, the United States, the Philippines, Morocco, and Tunisia (in http://www.pikiranrakyat.com/pendidikan/2016). Iskandarwassid and Sunendar (2010: 263) also stated that Indonesian language devotees are gradually increased. In several public schools in foreign country, Indonesian becomes one of the foreign languages is being studied. For example, France, New Zealand, Australia and Japan. In some neighboring tertiary institutions in Malaysia, Indonesian is one of the foreign languages department which is gradually becoming popular.

\section{Issues of Culture in BIPA Learning at Surakarta City State University Learning}

The teaching - learning activity process of Indonesian language involves several aspects, including: social, culture, integration, communication and pragmaticscs aspects (Supardo, 1988: 19). The social aspect is a means of communication between community members. By language, everyone can convey ideas and feelings to others. Language speakers are the members of the community.

Teaching BIPA in Surakarta City State University, there are several social aspects can be seen, namely that Indonesian language that is taught has an adapted context to the surrounding community which eventually they must use as a communication tool in the environment where they study. The cultural aspects of BIPA teaching in that place are seen both in terms of language and language attitude. In the way of communication with the parents, they are taught to use the words "Father", "Mother", or "Uncle" not by saying the word you anyway. To declare going to the afterlife we use the words "die", "passed away", or "gone". Integrative aspects, is that a language has sound elements consisting of words, phrases, clauses, and sentences. These elements are never separated from others. Every word will have no meaning if it is not accompanied by other words in language usage. The communicative aspect is the relationship of meaning in 
the language. The pragmatic aspect is the study of the usage of language that is related to the context, namely how language is used in communication. Thus, the teaching Indonesian for foreign speakers (BIPA) at State Universities in Surakarta City, which certainly cannot be separated from these aspects, especially the aspects of existed local culture of the society. This is the reason of language is a part of culture and as a means of conveying certain cultures. This is in accordance with Chaer (2006: 2) who stated that Indonesian itself has a position as a national language and the official language of the State in the midst of various regional languages, having these following functions. (1) Tools for carrying out state administration, all state administration activities must be held in Indonesian; (2) Unifying tools of various ethnic groups in Indonesia between members of different ethnic groups, which is impossible to use one of regional languages of a certain tribe. Communication is more likely to be done in Indonesian language. Due to this inter-tribal communication is carried out in Indonesian, it will create a feeling of "one nation" among the members of the tribes; (3) Media to accommodate national culture and regional culture can be accommodated in regional language media, but Indonesian national culture must be accommodated in Indonesian language media.

Culture-based BIPA learning will certainly help foreign learners in understanding Indonesian language and culture. Through cultural-based BIPA learning, a teacher or instructor of BIPA can easily internalize Indonesian cultures to foreign learners. In addition, the needs of BIPA students at Surakarta City State University certainly is not only mastering the language, but also mastering the diversity of Indonesian cultural content completely so that they can communicate in the context of Indonesian culture. This kind of understanding will greatly help them to adapt because of the differences between the cultural context of Indonesia and other countries.

According to Alimatussa'diyah (2016: 46) awareness of BIPA students about Indonesian culture will greatly help students in actualizing themselves appropriately in Indonesian. Cultural values that must be implemented into teaching materials include (1) Knowledge of the social and cultural life of the people in Indonesia; (2) Culture / characteristics of regions in Indonesia; (3) Systems / norms in Indonesia; (4) Regional tourism and arts in Indonesia.

Murtianis (2019) who have used one of the media in BIPA learning to introduce Indonesian culture, especially Javanese culture, is the use of textbooks. Textbooks are used as an intermediary for aspects of Javanese culture that are not possible to be shown directly to foreign students as BIPA learning subjects. The Javanese culture presented by the textbooks in BIPA learning includes 1) traditional transportation, 2) traditional food and drinks, 3) traditional arts, 4) traditional clothing, and 5) ancient temples in Java. The media was used in accordance with the objectives of BIPA learning at Sebelas Maret University, namely to introduce Javanese culture. The introduction of Javanese culture in BIPA learning is considered important because Sebelas Maret University is located on Java Island, namely Central Java.

Therefore, throughout the cultural-based BIPA learning, a BIPA teacher can easily introduce Indonesian cultural values, both physical and non-physical cultures to foreign learners. According to Mussaif (2016: 253) physical culture that can be taught in BIPA learning are tourist attractions and Indonesian cultural sites aim to provide knowledge about the diversity of cultural products and show the amazing tourist destinations. Meanwhile, non-physical culture can be appeared as songs, folklore, customs, and community traditions which can provide the spirit of tenderness, harmony and uniqueness that touch the psychological side. Physical culture in this context, for example, if the learning program is held in Bandung, the teaching material could be form of texts related to the learning environment, for example the legend of Tangkuban Perahu, some unique places in Bandung, and many kinds of special culinary of Bandung. This aims to provide a concrete experience to the learner. If possible, within a certain period a teacher can carry out outdoor learning by observing the cultural content that is taught directly or it can be also through certain media so that the learners can learn the language while recognizing Indonesian culture.

Furthermore, another method that can also be used is carrying out learning by introducing nonphysical culture such as songs as be performed at Sebelas Maret University Surakarta. The level of difficulty of the song certainly depends on the level or degree of the learners. For example, students can present the song "Tanah Air". The song explicitly saves the meaning of culture to introduce Indonesia.

However, cultural-based BIPA learning does not mean that culture is a priority. In this context, mastering the language remains the main thing. Culture is only a means of mastering language as well as 
being an additional knowledge for foreign students. This learning will also be more effective if it is implemented integratively so that there is no special separation between the competencies of each language skill. Therefore, a certain competencyy can teach some language skills. Furthermore, the culture that is taught also adapted to the needs of the learner, as well as the song which must be adjusted to the level of understanding and mastering language of foreign learners; so that the teaching material becomes relevant to the level or degree of the learners' mastery of the language.

By those learning, a BIPA teacher can help foreign students to master Indonesian easily and able to understand the content of the culture being taught. The strong interest of foreign students towards Indonesian will make Indonesian language known globally so that it certainly gives an opportunity for Indonesian language to become one of the international languages. However, this program and expectation certainly will be achieved by the support of the government. It is proper for the Indonesian government to formulate a special policy on standardization of mastery of Indonesian language for foreign students who will settle in Indonesia with various interests. By the existence of the authorized standards by the government, foreign students are also required to recognize Indonesian language and culture; so that this opportunity can be means or connector for Indonesian language to be more existed in the international territory.

\section{Conclusion}

Culture-based BIPA learning can be done in various ways, such as by introducing physical and nonphysical culture. BIPA learning is based on the physical culture, for example by taking the content of tourist attractions and objects that becomes a distinctive characteristic of a certain region. Meanwhile, the physical culture such as songs or traditions of a certain region. This cultural content certainly can be included in teaching materials in BIPA learning to help the foreign learners mastering the desired language skills. The suggestions for this research are that BIPA teachers can introduce the culture found in Solo through various practical activities to improve the ability to speak, write, listen and listen. Students can also be invited to visit one of the traditional specialties in Solo. Thus they can find out the process of making these foods. In addition, the teacher can also invite students to visit places that have historical value in Solo. Culture-based BIPA learning still emphasizes mastery of Indonesian as the main orientation. The cultural aspect in this context is merely as a means of language mastery skill. In addition, the implementation of culture-based BIPA learning is also carried out integratively so that there is no separation inter certain language skills. The limitation of this study is that researchers only conduct research with a small sample. In Surakarta there are still other universities that have BIPA programs. However, researchers only focus on research at State Universities. This research can be followed up by other researchers who will examine things similar to the broader object of research.

\section{REFERENCES}

Alimatussa'diyah (2016). Pengimpelementasian Nilai-Nilai Budaya Dalam Bahan Ajar BIPA. Prosiding, Universitas Negeri Semarang, Semarang, Hal. 46.

Aslinda dan Leni Syafyahya (2010). Pengantar sosiolinguistik. Bandung: PT Refika Aditama.

Azizah, dkk (2012). Pembelajaran BIPA program CLS (critical language scholarship) di Fakultas Sastra Universitas Negeri Malang. Malang: Universitas Negeri Malang.

Chaer, A. dan Agustina, L. (2004). Sosiolinguistik perkenalan awal. Jakarta: PT Rineka Cipta.

Chaer, A. (2006). Tata bahasa praktis bahasa Indonesia. Jakarta: Pt Rineka Cipta.

Hood, S., Hopson, R., \& Frierson, H. (2005). The role of culture and cultural context: A mandate for inclusion, the discovery of truth and understanding in evaluative theory and understanding in evaluative theory and practice. Greenwich, CT: Information Age Publishing.

Hudjolly (2011). Bahasa Indonesia Di Mata Dunia. Raja Ali Haji. (Diakses dari http://www.rajaalihaji.com pada tanggal 4 Januari 2016).

Iskandarwassid dan Dadang Sunendar.(2010). Strategi Pembelajaran Bahasa. Bandung: PT Remaja Rosdakarya. 
Rachman,I.F., Andayani \& Suyitno (2019). Cultural issues in Indonesian language learning for foreign speakers. International Journal of Educational Research Review,4(3),454-460.

Julianto, H.D. \& Subroto, W.T. (2019). Multicultural education based on local education in elementary school. International Journal of Educational Research Review, 4 (3), 420-426.

Lee, C. D. (2009). Cultural influences on learning. In J. A. Banks (Ed.), The Routledge International companion to multicultural education (pp. 239-251). New York: Routledge.

Lee, C. D., Spencer, M. B., \& Harpalani, V. (2003). Every shut eye ain't sleep: Studying how people live culturally. Educational Researcher, 32 (5), 6-13.

Murtianis, Andayani \& Muhammad Rohmadi (2019). Text book as a Java culture recognition media in Indonesian learning for foreign speaker (BIPA) in Sebelas Maret University. International Journal of Educational Research Review, 4 (3), 427-434.

Mussaif, Moh. Muzakka. (2016). Pembelajaran BIPA Berbasis Budaya. Prosiding, Universitas Negeri Semarang, Semarang, Hal. 253

Orellana, M. F., \& Bowman, P. (2003). Cultural diversity research on learning and development: Conceptual, methodological, and strategic considerations. Educational Researcher, 32 (5), 26-32.

Pamungkas, S. (2012). Bahasa Indonesia Dalam Berbagai Perspektif. Yogyakarta: ANDI.

Supardo, S. (1988). Bahasa Indonesia Dalam Konteks. Jakarta: Departemen Pendidikan dan Kebudayaan.

Swartz, E. (2009). Diversity: Gatekeeping knowledge and maintaining inequalities. Review of Educational Research, 79, 1044-1083.

Thanasoulas, D. (2001). Radical pedagogy: The importance of teaching culture in the foreign language classroom. Retrieved from the International Consortium for the Advancement of Academic Publication Web site: http://radicalpedagogy.icaap.org/content/issue3_3/7-thanasoulas.html

Warikoo, N. (2009). Cultural explanations for racial and ethnicstratification in academic achievement: A call for a new and improved theory. Review of Educational Research, 79 (1), 366-394.

Wardhaugh, R. (2002). An introduction to sociolinguistics (Fourth Ed.). Oxford: Blackwell Publishers.

Lambert, W. (1975). Culture and language as factors in learning and education. In A. Wolfgang (ed.) Education of Immigrant Students. Toronto: Ontario Institute for Studies in Education.

LaFromboise, T., Coleman, H. \& Gerton, J. (1993). Psychological impact of biculturalism: Evidence and theory. Psychological Bulletin, 114 (3), 395-412.

Brecht, R.D. \& Ingold, C.W. (1998). Tapping a national resource: Heritage languagesin the United States. Washington DC: National Foreign Language Center Occasional Paper (NFLC).

Brecht, R.D. \& Walton, A.R. (1993) National strategic planning in the less commonly taught languages. Washington DC: National Foreign Language Center Occasional Paper (NFLC).

Hamers, J. \& Blanc, M. (1993). Bilinguality and bilingualism. New York, NY: Cambridge University Press 